\title{
Effects of Season and Waterbody on Transparency Tube Estimates of Suspended Sediment in Large Rivers
}

\author{
1, 2* JOHNSON, KS; ${ }^{3}$ FANG, Y; ${ }^{3}$ CHANG, T \\ ${ }^{1}$ Department of Biological Sciences, Ohio University, Athens $\mathrm{OH} 45701$ \\ ${ }^{2}$ Voinovich School of Leadership and Public Affairs, Ohio University, Athens $\mathrm{OH} 45701$ \\ ${ }^{3}$ Department of Civil Engineering, Russ College of Engineering and Technology, Ohio University, Athens OH 45701 \\ *Corresponding author Email: johnsok3@ohio.edu, Tel: 740-593-0276
}

\begin{abstract}
This paper reports the measurement $(\mathrm{N}>132)$ of the effect of river and season on transparency in $\mathrm{cm}$ and Total Suspended Solids in $\mathrm{mg} / \mathrm{L}$ in a navigational pool of the Ohio River and one of its tributaries, the Muskingum River. Both river of origin and season affected water transparency. The transparency-TSS relationship was stronger in spring $\left(R^{2}=0.894\right)$ than autumn $\left(R^{2}=0.710\right)$, with an overall correlation of $R^{2}=0.86$ for $\mathrm{N}=93$ observations in both water bodies and seasons. Regression equations for the transparency-TSS relationships for the two rivers under low (autumn) and high (spring) flow conditions were developed. Our study demonstrates that properly trained volunteers can assist with rapid assessment of water turbidity from suspended solids in large rivers, reservoirs and lakes, but seasonal calibration of these measures will improve accuracy of sediment monitoring and management.
\end{abstract}

\section{DOI: https://dx.doi.org/10.4314/jasem.v22i10.09}

Copyright: Copyright $\odot 2018$ Johnson et al. This is an open access article distributed under the Creative Commons Attribution License (CCL), which permits unrestricted use, distribution, and reproduction in any medium, provided the original work is properly cited.

Dates: Received: 30 July 2017; Revised: 15 October: 2018; Accepted: 21 October 2018

Keywords: Transparency tube, turbidity, monitoring, sediment transport, citizen science, water quality

Control of suspended solids in lakes and rivers is an important element of integrated watershed land use and water management policy. Suspended solids that enter during periods of high precipitation and surface flow often correlate with an influx of nutrients (phosphorous), reduced light penetration, and altered benthic habitat (Bilotta and Brazier 2008). Transparency tubes are rapid, economical tools for assessing water clarity in lakes, reservoirs and rivers. Since the 1990s they have been adopted by monitoring programs around the world (Sovell et al. 2000; Schloss et al. 2004; Uzarski 2012). They are increasingly used by researchers interested in effects of dam removal and suitability of habitat for aquatic biota (Fuller et al. 2011; Laplante-Albert et al. 2010; Reid et al. 2015; Rumschlag and Peck 2007). Interpretation of transparency measures depends on the hydrological characteristics of the waterbody. In lakes, transparency measures are interpreted like traditional Secchi depths to estimate light penetration and evaluate trophic status (e.g. oligotrophic, mesotrophic or eutrophic). Especially in summertime, suspended solids are primarily of biological origin (phytoplankton, zooplankton, organic detritus), and algal biovolumes correlate with light and nutrient availability. In streams and rivers, transparency measures are indicators of silt and other non-biological suspended particles (Davies-Colley and Smith 2001; Dahlgren et al. 2004) and can be used as surrogates for TSS (Anderson and Davic 2004; Smith et al. 1997) and used to estimate erosion and sediment transport. We investigated seasonal differences in the transparency-TSS relationship related to precipitationdriven surface runoff and whether volunteer-collected transparency tube measurements are comparable to those made by professionals. Prior studies have shown that transparency tube measures in streams correlate reasonably well with TSS, but few have evaluated additional factors such as season, catchment size and land use, hydrological regime, or nutrients. We examined correlations of transparency $(\mathrm{cm})$ with total suspended solids (TSS, in $\mathrm{mg} \mathrm{L}^{-1}$ ), dissolved phosphate and nitrogen in navigational pools of a large dammed rivers (the Ohio River) and a tributary (Muskingum River) over 5 years. Transparency measures were collected by teams of citizen scientists (high school students and their teachers). The correlations of their TSS-transparency tube measurements were compared to those reported in published literature to evaluate whether volunteer data is as credible as that collected by professional scientists. This reinforces a key element of successful partnerships between researchers and citizen/community organizations (Conrad et al. 2011; 
Sharp and Conrad 2006) and suggests economical ways that TSS in rivers can be monitored. Our objective was to demonstrate how transparency tube measurements by citizen scientists or volunteers can be calibrated and used for long term monitoring of suspended sediment in rivers.

\section{MATERIALS AND METHODS}

The two studied rivers are located in eastern North America. The Ohio River flows for more than 1,657 $\mathrm{km}$ until it meets the Mississippi River. It is an important navigable transportation route and is impounded by a series of locks and dams that divide it into a total of twenty navigational pools along its length. Samples were collected along a $16 \mathrm{~km}$ transect in the Belleville Pool approximately $40 \mathrm{~km}$ upstream of the dam, above and below the confluence with the Muskingum River. Water depth ranges from 3-9 meters in this section.

The Muskingum River is a large tributary of the Ohio, approximately $179 \mathrm{~km}$ long with a drainage area of $22,995 \mathrm{~km}^{2}$. Land use in the basin is largely agricultural and/or forested, with small areas of urban development. The Muskingum is navigable due to a series of small locks and dams. Water samples were collected 1.5-6.5 km upstream of the river's confluence with the Ohio River and downstream of the first lock and dam system. The river depth ranged from 3-6 meters in this section. Both rivers were sampled during the same times (usually the same day).

Water samples along the study transects were collected by boat over a five year period (2010-2014) period, for 3-4 weeks in spring (April-May) and again in autumn (Sept-Oct). Samples were collected from a research vessel by a crew of researchers working with teachers and high school students. Students were trained in water sampling protocols and the use of transparency tubes in the classroom before performing measures on the boat, and each measurement was directly supervised by an experienced crew member.

Water samples were collected at $0.1,1,2$ or 3 meters depth using either a bucket (for surface samples) or a Kemmerer sampler. Transparency was measured with a clear plastic $120 \mathrm{~cm}$ transparency tube with a valve on the bottom, filled and assessed three times per site/sample. Measurements were recorded in the shade, out of direct sunlight.

Total suspended solid samples from the grab samples were analyzed using ASTM Standard Test Method B (ASTM 1997). This method is for Total Suspended Sediment Concentration (SSC), which differs slightly from the ASTM method for TSS (APHA 1995) in that all of the collected sample (not a subsample) is filtered and measured. In this regard, the SSC measure is more similar to the U. S. EPA's TSS method (1999) which also stirs and uses the entire sample volume. The total volume of the water sample was measured and filtered under vacuum through a pre-weighed Millipore $^{\mathrm{TM}}$ AP4004700 glass fiber filter (47 mm diameter and 0.7 $\mu \mathrm{m}$ pore size). Solids were transferred to a drying oven set to $105^{\circ} \mathrm{C}$ for $2 \mathrm{~h}$, allowed to cool to room temperature with desiccant, then weighed.

Correlations and regression equations were generated using SPSS software (IBM Corp, 2010). Main effects and interactions of river and season on transparency, nitrate, and phosphate were analyzed using a Generalized Linear Model. TSS was included as a covariate for effects on transparency.

\section{RESULTS AND DISCUSSION}

A dataset of $n=132$ observations from the Ohio and Muskingum rivers was compiled from spring (2011 and 2014) and autumn (2010, 2012, 2013) measurements. The majority of samples were collected at shallow depth, between 0.1 and 1.0 meters $(n=132)$. Only 17 were collected at 2.0-3.0 meters. Eleven of the transparency measures were at or above the detection level of the transparency tube (e.g. when water transparency exceeded the full length of the tube, $120 \mathrm{~cm}$ ), and when these were removed, linear regression analysis showed a strong positive correlation between log-transformed transparency $(\mathrm{cm})$ and gravimetric measures of TSS $(\mathrm{mg} / \mathrm{L})$ (Figure $\left.1, R^{2}=0.86, P<0.0001\right)$. The correlation was described by the equation:

$$
\log (\text { TSS })=-0.5468 x+2.1965
$$

Where TSS = laboratory gravimetrically determined TSS (or Suspended Solid Concentration) in $\mathrm{mg} / \mathrm{L}$ and $\mathrm{x}=$ transparency tube reading in $\mathrm{cm}$.

Further analysis by two-way ANOVA revealed significant effects of river $(d f=1$, mean squares $=$ $0.067, F=4.80, P=0.031)$ and season $(d f=1$, mean squares $=0.057, F=4.075, P=0.047$ on transparency, as well as an interaction $(d f=1$, mean squares $=0.078$, $F=5.557, P=0.020)$.

The transparency-TSS relationship was stronger in spring $\left(R^{2}=0.894\right)$ than in autumn $\left(R^{2}=0.710\right)$ (Figure 2). Both rivers experienced higher discharge and suspended sediment concentrations in the rainy spring season compared to lower flows in autumn months. These seasonal differences are important to understand if the transparency tube is to be employed as a surrogate for TSS year round. 


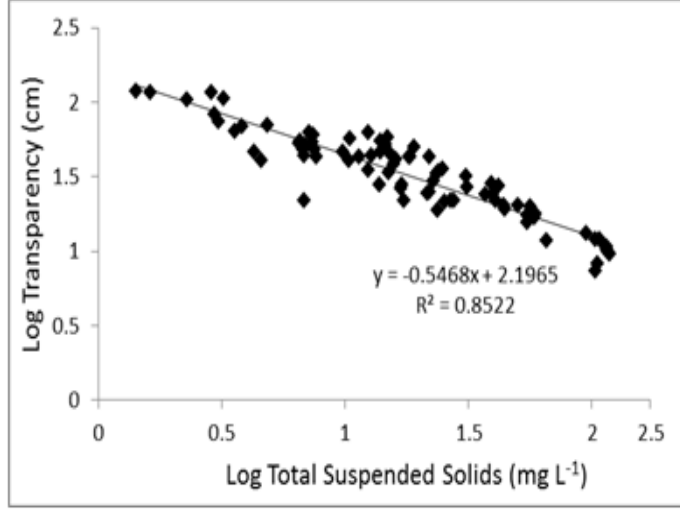

Fig 1. Linear regression of transparency tube measures with gravimetric measures of suspended sediment in the Ohio and Muskingum rivers, pooled across years and seasons $(\mathrm{n}=93)$. Transparency measurements $(\mathrm{cm})$ and TSS $\left(\mathrm{mg} \mathrm{L}^{-1}\right)$ were log transformed prior to analysis.

The seasonally adjusted correlation equations are

Spring $\log (T S S)=-1.1487 x+3.1693$

Autumn $\log (T S S)=-0.4656 x+2.1313$

Where TSS = laboratory gravimetrically determined TSS (or Suspended Solid Concentration) and $\mathrm{x}=$ transparency tube reading in $\mathrm{cm}$.

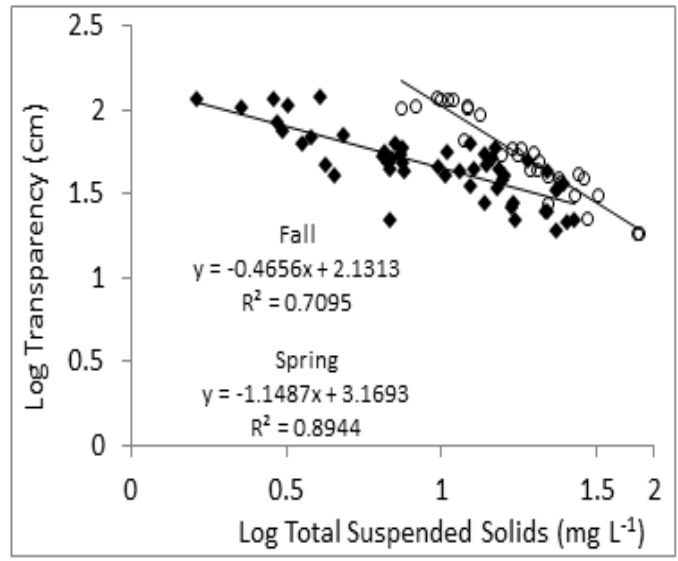

Fig 2. Linear correlation of transparency tube measures $(\mathrm{cm})$ with TSS (mg/L) in autumn (lower flow) and spring (higher average flow) for both Muskingum and Ohio rivers combined.

Figures $3 \mathrm{a}$ and $\mathrm{b}$ further illustrate how the relationship between transparency and TSS in the Ohio and Muskingum rivers differs relative to season. The Muskingum River had consistently higher TSS than the Ohio regardless of season, although in both waterways suspended solids were highest during higher spring flows. The stronger correlations between transparency and TSS in the Ohio may be because more samples were collected from the Ohio than the Muskingum during the study period.

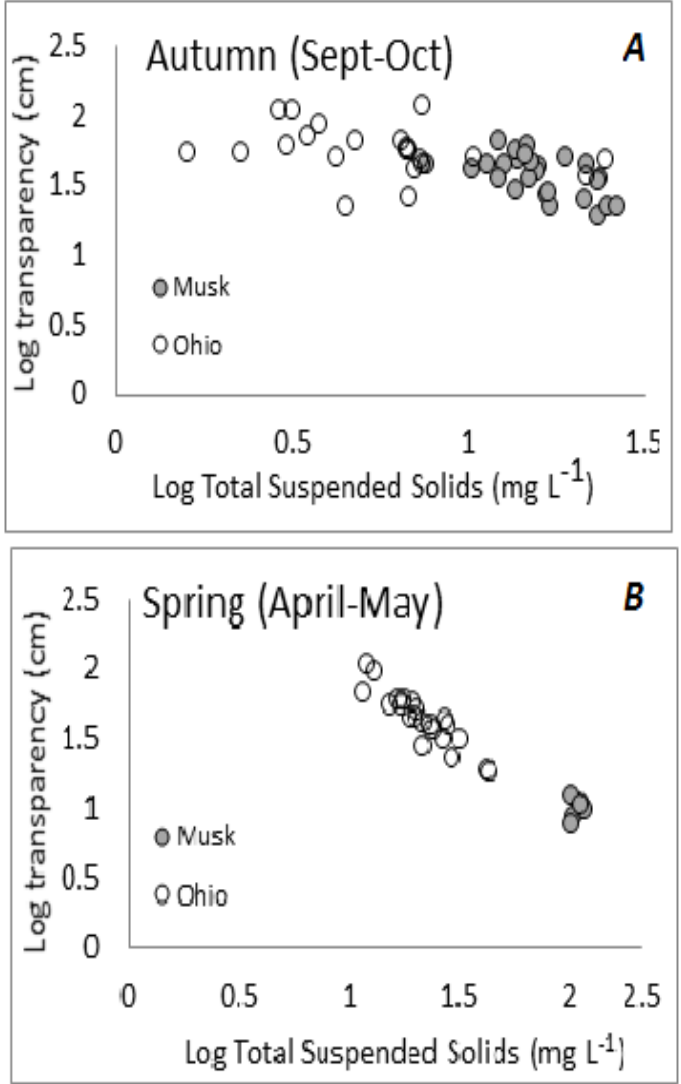

Fig 3A and B. Relationship between transparency $(\mathrm{cm})$ and TSS $(\mathrm{mg} / \mathrm{L})$ in the Ohio River and its tributary, the Muskingum in A) autumn and B) spring

The dataset included 102 measurements of total $\mathrm{N}$, total $\mathrm{P}$ and transparency. Nutrients differed between the two rivers and were also affected by season (Figure 4). Total dissolved phosphate in filtered water samples ranged from $<0.50$ to $2.0 \mathrm{mg} / \mathrm{L}$ and were higher in the Muskingum than Ohio $(d f=1, M S=8.595, F=17.890$, $P<0.0001)$, and higher in spring $(d f=1, M S=6.666$, $F=13.875, P<0.0001)$. There was a significant river x season interaction $(d f=1, M S=2.878, F=5.990, P$ $=0.016$ ), with the Muskingum displaying stronger seasonal differences than the Ohio. Nitrogen did not differ between rivers $(d f=1, M S=0.963, F=3.412$, $P=0.068)$ or season $(d f=1, M S=0.017, F=0.590, P$ $=0.808)$, although there was a significant river $\mathrm{X}$ season interaction $(d f=1, M S=1.831, F=6.490, P=$ $0.010)$. Our study demonstrates that transparency tube measures collected by volunteers can provide reliable estimates of TSS in large rivers. The correlation of transparency tube measures of water clarity and labperformed gravimetric measures of TSS across both rivers and seasons $\left(R^{2}=0.86\right)$ is similar to that collected by non-volunteers in previous studies (Anderson and Davic 2004; Sovell et al. 2000). Dahlgren et al. (2004) found lower correlations between transparency and TSS across 12 California 
streams and rivers $\left(R^{2}=0.51-0.60\right)$, although correlations of repeated measures within a single river over a full water year were stronger $\left(R^{2}=0.78\right)$.

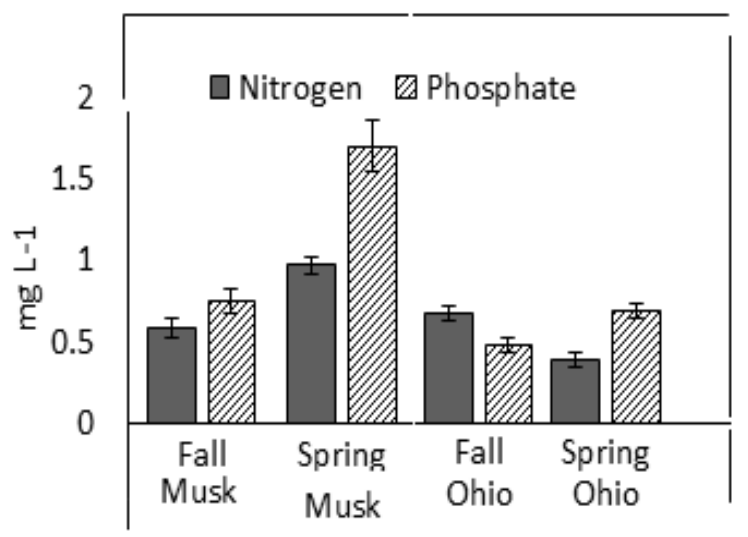

Fig 4. Total dissolved phosphate was higher in the Muskingum than Ohio ( $d f=1, M S=8.595, F=17.890, P<0.0001, n=102)$, and higher in spring $(d f=1, M S=6.666, F=13.875, P<0.0001)$ compared to autumn. Nitrogen did not differ between rivers $(d f=1$, $M S=0.963, F=3.412, P=0.068)$ or season $(d f=1, M S=0.017, F$ $=0.590, P=0.808$ ).

Estimations of suspended solids in lakes, reservoirs and rivers are used by managers to evaluate and monitor long term changes in water quality, seasonal or storm related sediment loading events, and to evaluate the effectiveness of restoration or management. Although nephelometric or gravimetric methods provide more precise measures of turbidity and TSS, transparency tubes are an economical option for rapid or repeated estimations. Their low cost and ease of use make them particularly valuable for quantifying changes in TSS in a particular water body at different periods of time (during and after precipitation events, during the first flush of the ascending limb of the hydrograph, during different seasons, for example). Anderson and Davic (2004) reported that accurate estimation of TSS in the lower ranges $(10-20 \mathrm{mg} / \mathrm{L})$ is more difficult with shorter transparency tubes, due to low repeatability, while longer tubes, such as the $120 \mathrm{~cm}$ model used in this study, allow detection to as low as $5.0 \mathrm{mg} / \mathrm{L}$. Whereas previous studies focused on transparency during summer flows, our study investigated differences between the steady high flow and peak events that occur in spring, compared to late summer and autumn. The stronger correlations between transparency in $\mathrm{cm}$ and TSS $\left(R^{2}=0.89\right)$ in spring compared to autumn $\left(R^{2}\right.$ $=0.71)$ were consistent with higher discharges in winter and spring compared to late summer and fall in the study region. For example, the mean monthly discharge of the Ohio River sites in May for the years 2009-2014 averaged 1,286 \pm 232 cubic meters/ sec $( \pm$ SE) in May and $463 \pm 109 \mathrm{~cm} / \mathrm{s}$ in September. The
Muskingum River averaged $285 \pm 59 \mathrm{~cm} / \mathrm{s}$ in May and $64 \pm 10 \mathrm{cms}$ in September (data from ORSANCO, 2015). Both rivers exhibited higher TSS content (in $\mathrm{mg} / \mathrm{L}$ ) in spring. The Muskingum River had higher suspended solids compared to the Ohio in both spring and autumn and appeared to be a significant contributor of sediments to the latter. High TSS often correlates with phosphorus inputs in some systems, since this nutrient frequently enters streams and lakes bound to sediment particles (Grayson et al. 1996).

This work demonstrates that seasonally adjusted TSStransparency regressions will be of greatest utility to water quality managers who are interested in monitoring sediment transport in slow-turnover reservoirs and navigational pools of larger rivers. Our findings also more generally support the use of transparency tubes by volunteers for rapid, economical monitoring of suspended solids in flowing waters for other purposes. Lake managers already familiar with the use of transparency and Secchi depth measures for assessing trophic status and within-lake sediment mixing can also use transparency tube measures to manage TSS loadings entering lakes, reservoirs or wetlands. Volunteer-monitoring with transparency tubes can help reduce the high cost and frequency of TSS sampling of feeder streams and rivers. Monitoring throughout the water year (Chow-Fraser 1999) can help account for seasonal, interannual and spatial variation in loadings. Their ease of use makes them particularly suitable for community-based monitoring, which is increasingly being used to provide credible data to agencies and water managers (Conrad 2011; Kolok et al. 2011; Loperfido et al. 2010,).

Acknowledgments: We thank the volunteers who participated in the Boat of Knowledge in Science Classroom (BooKS) project funded by National Science Foundation (\#0947813). Special thanks to Captain Dave Diggle and the Valley Gem Sternwheeler crew. Funding was also provided by the Ohio Board of Regents, Ohio University's Russ Colleges of Engineering and Arts and Sciences, and the American Electric Power Foundation.

\section{REFERENCES}

Anderson, P; Davie, RD (2004). Use of transparency tubes for rapid assessment of total suspended solids and turbidity in streams. Lake and Reservoir Management 20(2):110-120.

American Public Health Association (APHA), American Water Works Association (AWWA) and Water Environment Federation (WEF). (1995). 2540 D: Total suspended solids dried at 103-105 C. In A. D. 
Eaton, L. S. Clesceri and A. E. Greenberg (Eds.), Standard Methods for the Examination of Water and Wastewater, $19^{\text {th }}$ edition, Washington, D.C.

ASTM. (1997). Standard Test Methods for Determining Sediment Concentration in Water Samples (ASTM Standard D3977, reapproved 2002). ASTM International: West Conshohocken, PA.

Bilotta GS; Brazier RE (2008). Understanding the influence of suspended solids on water quality and aquatic biota. Water Research 42(12): 2849-2861.

Chow-Fraser P (1999). Seasonal, interannual, and spatial variability in the concentrations of total suspended solids in a degraded coastal wetland of Lake Ontario. Journal of Great Lakes Research 25(4): 799-813.

Conrad, CC; Hilchey, KG (2011). A review of citizen science and community-based environmental monitoring: issues and opportunities. Environmental Monitoring and Assessment 176(1-4): 273-291.

Cowell, BC; Dawes, CJ (2008). Seasonal comparisons of the phytoplankton and decline in water transparency in the spring-fed Rainbow River, Florida. Journal of Freshwater Ecology 23(2): 169-177.

Dahlgren, R; Van Niewenhuyse, E; Litton, G (2004). Transparency tube provides reliable water-quality measurements. California Agriculture 58(3):149153

Davies-Colley RJ; Smith DG (2001). Turbidity, suspended sediment, and water clarity: A review. Journal of the American Water Resources Association 37(5):1085-101

Fuller, TE; Pope, KL; Ashton, DT;Welsh, HH (2011). Linking the distribution of an invasive amphibian (Rana catesbeiana) to habitat conditions in a managed river system in northern California. Restoration Ecology 19(201):204-213.

Grayson, RB; Finlayson, BL; Gippel, CJ; Hart, BT (1996). The potential of field turbidity measurements for the computation of total phosphorus and suspended solids loads. J. Environmental Management 47:257-267.

Kolok AS; Schoenfuss HL; Propper CR; Vail TL (2011). Empowering citizen scientists: The strength of many in monitoring biologically active environmental contaminants. BioScience 61(8): 626-630.
Laplante-Albert, KA; Rodríguez, MA; Magnan, P (2010). Quantifying habitat-dependent mortality risk in lacustrine fishes by means of tethering trials and survival analyses. Environmental Biology of Fishes, 87(3): 263-273.

Loperfido, JV; Beyer, P; Just, CL; Schnoor, JL (2010). Uses and biases of volunteer water quality data. Environmental Science \& Technology, 44(19), 7193-7199.

ORSANCO. http://www.orsanco.org/national-weatherservice-ohio-river-flow-and-velocity/3mainpages/data/328-monthly-average-stream-flows Accessed June 27, 2015.

Reid, SM; Nocera, JJ (2015). Composition of native crayfish assemblages in southern Ontario rivers affected by rusty crayfish (Orconectes rusticus Girard, 1852) invasions-implications for endangered queensnake recovery. Aquatic Invasions 10(2): 189-198.

Rumschlag, JH; Peck, JA (2007). Short-term sediment and morphologic response of the middle Cuyahoga River to the removal of the Munroe Falls Dam, Summit County, Ohio. Journal of Great Lakes Research 33:142-153.

Schloss, J; Ely E (2004). Measuring Clarity, Transparency, Turbidity, and TSS. 2004. Volunteer Monitor National Newsletter of Volunteer Water Quality Monitoring. Winter Edition.http://www.epa.gov/owow/monitoring/volu nteer/newsletter/volmon16no1.pdf

Sharpe, A; Conrad, C (2006). Community based ecological monitoring in Nova Scotia: challenges and opportunities. Environmental Monitoring and Assessment, 113(1-3): 395-409.

Smith, DG; Davies-Colley, RJ; Knoef, J; Slot, GWJ (1997). Optical characteristics of New Zealand rivers in relation to flow. Journal of the American Water Resources Association 33:301-312. doi: 10.1111/j.1752-1688.1997.tb03511.x

Sovell, L; Heiskary, S; Anderson, J; Sovell, L (2000, April). Using the transparency tube in Minnesota's new Citizen Stream Monitoring Program. In Proceedings of the 1999 National Water Quality Monitoring Conference. Pp. 481-493.

Uzarski, DG (2012). GLIC: Implementing Great Lakes coastal wetland monitoring. Quality Assurance Project Plan for the US EPA. 